\title{
Elementary Chemical Analysis in Leaves Infected by Fumagina by X-Ray Fluorescence Technique
}

\author{
Maria Sélia Blonski ${ }^{1}$, Carlos Roberto Appoloni ${ }^{1}$, Paulo Sérgio Parreira ${ }^{1}$, Pedro Henrique \\ Arruda Aragão ${ }^{1}$ and Virgilio Franco Nascimento Filho ${ }^{2}$ \\ ${ }^{1}$ Universidade Estadual de Londrina; Centro de Ciências Exatas; Departamento de Física; C.P.: 6001; Londrina - \\ PR - Brasil. ${ }^{2}$ Universidade de São Paulo; Center of Nuclear Energy in Agriculture - Piracicaba - SP - Brasil.
}

\begin{abstract}
Energy Dispersion X-Ray Fluorescence Technique (EDXRF) was employed to study the effects of the fumagina disease on the elementary chemical composition of the leaves. The experimental set up consisted of a Mo X-ray tube $\left(K_{\infty}=17.44 \mathrm{keV}\right)$ with $\mathrm{Zr}$ filter and a Si $(\mathrm{Li})$ detector. The measurements were performed with the infected and healthy leaves of citric plants. The elements Ti, $\mathrm{Mn}, \mathrm{Fe}, \mathrm{Cu}$ and $\mathrm{Zn}$ were quantified, with an average DL of 69, 12, 8, 4 and $4 \mu \mathrm{g} \cdot \mathrm{g}^{-1}$ respectively. The obtained concentration for Fe varied from 44 to $192 \mu \mathrm{g} \cdot \mathrm{g}^{-1}$ in healthy leaves and from 363 to $704 \mu \mathrm{g} . \mathrm{g}^{-1}$ in infected leaves with fumagina.
\end{abstract}

Key words: Fumagina, leaves, fluorescence of X-rays

\section{INTRODUCTION}

Several microorganisms including fungus and virus infect Citrus plants. "Fumagina" is an association of fungus, which presents a soot coloration and attack Citrus trees, producing a yellow cover and fall of the leaves, reducing the size and amount of the fruits" (Fanta et al.,1992). Fumagina is produced by the Capnodium fungi (Almeida et al.,2003), a fungus from Dothideales order that lives associated with the yellow aphid ( Monelliopsis pecanis), excreting a heavy load of a sugary substance that provides the sooty fungus development, covering, in some cases in totality, of leaves, fruits and branches surfaces (Aragão et al., 2001). The physical block of the photosynthesis is one of the largest problems caused by the disease. This reduction in the photosynthesis, however, affects the reserves of carbohydrates in the plant, resulting in the reduced and bad quality harvests. If the harvest is not treated at the proper time, it can be lost, causing damages to the agriculture, especially of areas of citric plantations. The technique of fluorescence $\mathrm{X}$-rays for dispersion of energy (EDXRF), is a versatile technique of low cost, non- destructive and fast in the simultaneous determination of many elements. It requires small amount of samples and many of them can be analyzed without any special preparation. The qualiquantitative analysis of elements with the $\mathrm{X}$-rays fluorescence technique bases on the measurement of the characteristic X-rays emitted by the elements of interest contained in the sample, when properly excited. The measured intensities of these characteristic X-rays are directly proportional to the concentrations of the elements in the sample. The characteristic X-ray emitted has its origin in the electronic transitions between the most internal layers ( $\mathrm{K}, \mathrm{L}, \mathrm{M}$ and $\mathrm{N})$. When one electron jump

\footnotetext{
${ }^{*}$ Author for correspondence
} 
from external level to internal level, it is followed by the emission of an X-ray with very defined energy or wave length, characteristic of the element.(Lachance, 1994). The analysis by X-rays fluorescence consists of three phases: excitation of the elements that constitute the sample, dispersion and detection of the X-ray emitted. (Nascimento,1993). The samples used in this work were infected and healthy leaves of Citric plants orange and lemon trees (Rutaceae-Citrus spp). Through the EDXRF technique Aragão et al., (2001) have observed that in the healthy olive leaves, from Mediterranean area, the concentration of iron was smaller than the one of calcium, while in the plant leaves infected by fumagina this relation was inverted, observing a quite high amount of iron in relation to calcium. This was the only work in which the variation in the concentration of $\mathrm{Fe}$ was measured in the plants infected by fumagina. Ivanova et al., (1999), using the EDXRF technique with radionuclide sources, measured elements concentrations in four species of the healthy plant leaves. Guohui and Shouzhong (1995) reported the direct determination of 25 elements $(11 \leq Z \leq 82)$ in dry powdered plant materials by $X$-ray fluorescence spectrometry. It was using the pressed powder pellets of the plant samples, containing $1 \mathrm{~g}$ of the dry powdered material. The measured elements concentration was in the range from 0.2 to $30460 \mathrm{ppm}$, and the lower level detection (LLD) was in the range from 0.25 to $23.6 \mathrm{ppm}$. The aim of this work was to analyze the amount of the chemical elements in the healthy and fumagina infected leaves by EDXRF. Ajasa et al. (2004), using atomic absorption spectrophotometry, measured a total of 10 elements $(11 \leq \mathrm{Z} \leq 82)$ in powdered medicinal plant samples. The measured elements concentration was in the range from 0.21 to 36600 ppm.

\section{MATERIALS AND METHODS}

\section{Experimental Set-Up and Parameters}

The excitation of the samples was accomplished with a Mo X-ray tube $\left(\mathrm{K}_{\propto}=17.44 \mathrm{keV}\right)$ with $\mathrm{Zr}$ filter, whose operation conditions were $10 \mathrm{~mA}$ and $25 \mathrm{kV}$.It used a Canberra semiconductor $\mathrm{Si}(\mathrm{Li})$ detector, model SL $80175,80 \mathrm{~mm}^{2}$ of active area and resolution of $175 \mathrm{eV}$ for the $6.4 \mathrm{keV} \mathrm{Fe} \mathrm{X-ray}$ line.An Ag collimator of $6.3 \mathrm{~mm}$ diameter was used over the $\mathrm{Si}(\mathrm{Li})$ detector, in order to minimize the detection of dispersed radiation produced by the experimental arrangement and also to reduce the dead time. The time of excitation and detection for the samples was 300 seconds and varied from 100 to 500 seconds for the MicroMatter element standards. The measurements were accomplished at the Laboratory of Nuclear Instrumentation in the Center of Nuclear Energy in Agriculture, CENA/USP, Piracicaba, São Paulo. The data were analyzed at the Laboratory of Applied Nuclear Physics of the State University of Londrina, Paraná, using the software AXIL (Espen et al., 1977).

\section{Preparation of the Samples}

The samples of Bahia, Valência, native orange leaves and Tahiti lemon leaves collected in the School Farm of the Agronomy Department of the State University of Londrina were prepared and measured in three stages:

1) In natura: without any preparation. Three different leaves were collected and measured directly.

2) In tablets: the samples of leaves were washed and placed to dry in oven at $200^{\circ} \mathrm{C}$ during 48 hour. After drying, the samples were crushed and, using $1 \mathrm{~g}$ of this material, tablets of $3.1 \mathrm{~cm}$ of diameter were made by pressing the material at $12{\mathrm{t} . \mathrm{cm}^{-2}}^{2}$ for five seconds, resulting in a superficial density of $0.132 \mathrm{~g} . \mathrm{cm}^{-2}$. Three tablets of each kind of leaf were prepared for measurement.

3) Tablets with boric acid: $0.1 \mathrm{~g}$ of dry leaves material was diluted in $0.9 \mathrm{~g}$ of boric acid $\left(\mathrm{H}_{3} \mathrm{BO}_{3}\right)$. Tablets were made using $1 \mathrm{~g}$ of this mixture as described above. For all the stages 1, 2 and 3, three different samples of each leaf type of the considered Citric plants were measured and analyzed. For the calculation of the sensibility, the thin film standard manufactured by Micro Matter/U.S.A., was employed whose element concentrations are shown in Table 1. 
Table 1- Elemental concentrations of thin film standard .

\begin{tabular}{cc}
\hline Elements & $\begin{array}{c}\text { Concentrations } \\
\left(\boldsymbol{\mu g ~}_{\mathbf{~ c m}}^{-\mathbf{2}}\right)\end{array}$ \\
\hline $\mathrm{Ca}$ & 30.90 \\
$\mathrm{Ti}$ & 43.30 \\
$\mathrm{Mn}$ & 44.69 \\
$\mathrm{Fe}$ & 49.40 \\
$\mathrm{Cu}$ & 42.30 \\
$\mathrm{Zn}$ & 16.16 \\
\hline
\end{tabular}

\section{Quantitative Analysis - Emission and Transmission Method}

The concentration of the elements in the pellets was determined through the equation (Giauque et al.,1973) :

$$
c=\frac{I}{S \cdot A}
$$

Where:

$c$ - element concentration in the tablets $\left(\mu \mathrm{g} . \mathrm{cm}^{-2}\right)$

$\mathrm{S}$ - elementary sensibility of the analyte (cps. $\mu \mathrm{g}^{-}$ ${ }^{1} . \mathrm{cm}^{2}$ )

I - intensity of the analyte (cps)

A- absorption factor of the characteristic X-ray of the element of interest by the matrix (no dimensional)

The factor $\mathrm{A}$ is given by:

$$
\mathrm{A}=\frac{1-e^{-\chi \cdot \rho_{0} \cdot D}}{\chi \cdot \rho_{o} \cdot D}
$$

Where:

$$
\chi \rho_{0} \mathrm{D}=\ln \left[\frac{I^{\text {irrad }}}{I^{i r r a d+a m}-I^{a m}}\right]
$$

$\mathrm{I}^{\text {irrad }}$ - characteristic X-ray intensity of the element of interest $i$ from the irradiator $I^{\text {irrad+am }}$ characteristic X-ray intensity of the element of interest $\mathrm{i}$ transmitted by the sampleI ${ }^{\mathrm{am}}$ characteristic X-ray intensity of the element of interest i originated from the sample.

The conversion of the element concentrations in the pellets to the analyzed citric species leaves was accomplished through the equation:

$$
C_{f f}=C_{p} \cdot \frac{a}{y}
$$

Where:

$\mathrm{C}_{\mathrm{ff}}$ - element concentration in the fresh leaf $\left(\mu \mathrm{g} \mathrm{g}^{-}\right.$ $\left.{ }^{1}\right)$

$\mathrm{c}_{\mathrm{p}}$ - element concentration in the pastilles $\left(\mu \mathrm{g} \mathrm{cm}^{-2}\right)$ $\mathrm{a}$ - pellets area $\left(7.55 \mathrm{~cm}^{2}\right)$

and:

$$
\dot{y}=\frac{x}{y} \cdot m
$$

$y^{\prime}$ - ratio between the mass of fresh leaves and the mass of dry leaves powder

$x$ - mass of fresh leaves

$y$ - mass of dry leaves powder

$\mathrm{m}-0.1 \mathrm{~g}$, mass of dry leaves powder used to make the tablets

\section{Detection Limit}

The detection limit was calculated through the following equation (BERTIN,1975):

$$
D L=\frac{3}{S . A} \sqrt{\frac{I_{i_{(B G)}}}{t}}
$$

where: DL -detection limit for the analyte $\left(\mu \mathrm{g} . \mathrm{cm}^{-}\right.$ 2)

$\mathrm{I}_{\mathrm{i}(\mathrm{BG})}$ - intensity of background under analyte peak (cps)

A - absorption factor (no dimensional)

$\mathrm{t}$ - time of excitation and detection ( $\mathrm{s}$ )

Using standards of thin film manufactured by MicroMatter/USA, element sensibilities were calculated for $\mathrm{Ca}, \mathrm{Ti}, \mathrm{Mn}, \mathrm{Fe}, \mathrm{Cu}$ and $\mathrm{Zn}$. 


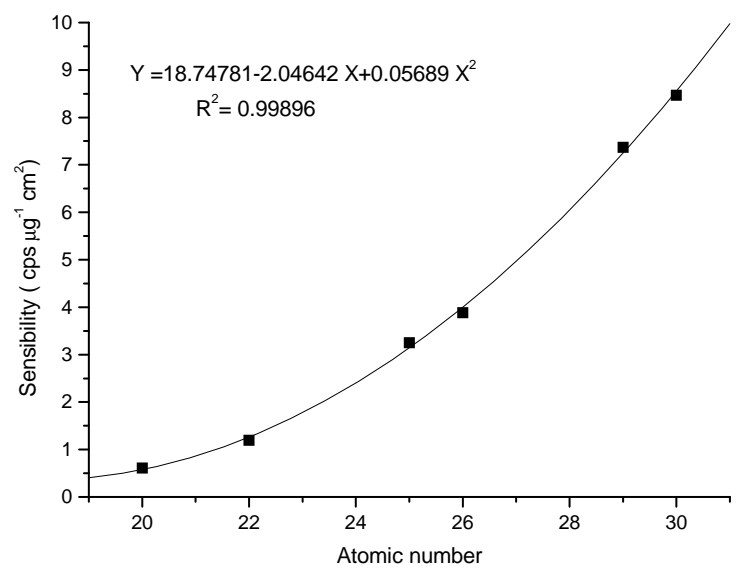

Figure 1 - Elementary sensibility in function of the atomic number for the Micro Matter standards

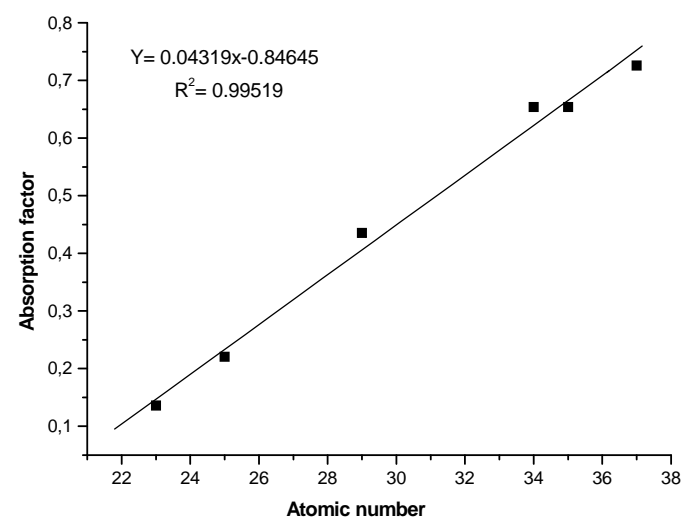

Figure 2 - Typical behavior of the absorption factor in function of the atomic number for a sample of Valência orange with fumagina

Fig. 1 displays the sensibility in function of the atomic number for the mentioned standard. Through the equation shown in the respective figure the sensibilities were calculated for the elements of interest. For all the biological samples, the absorption factors were determined with the aid of equation 2, using an irradiator containing the elements $\mathrm{V}, \mathrm{Mn}, \mathrm{Cu}, \mathrm{Se}, \mathrm{Br}$ and $\mathrm{Rb}$ (atomic numbers ranging from 23 to 38). Fig. 2 shows the relation between the absorption factor and the atomic number for a sample of Valência orange with fumagina. And for the sample of Valência orange with fumagina (Fig. 2 ). All the samples presented correlation between the absorption factor and the atomic number.

Fig. 3 displays the relation between the detection limit and the atomic number for the samples with fumagina analyzed in this work. For the atomic number 22, the detection limit varied between 50 and $86 \mu \mathrm{g} \cdot \mathrm{g}^{-1}$. For the atomic numbers from 25 to 30 , the detection limits were lower, varying between 2.8 and $15 \mu \mathrm{g} \cdot \mathrm{g}^{-1}$. 


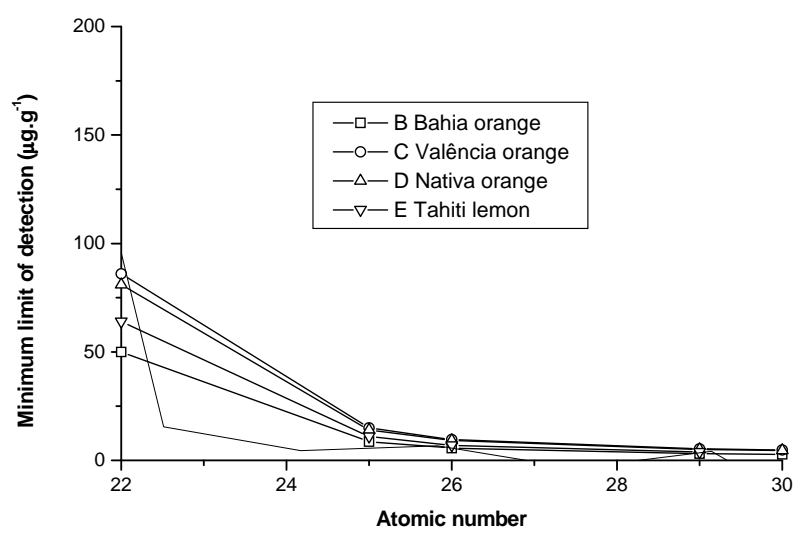

Figure 3 - Minimum limit of detection in function of the atomic number for the samples with fumagina

\section{RESULTS AND DISCUSSION}

Figs. 4 and 5 presents typical spectra of Bahia orange samples analyzed in natura, with and without fumagina, respectively.

For the other samples analyzed, Valencia orange, Native orange and Tahiti lemon, the spectra were similar. The spectra presented at Figs. 4 and 5 show the concentration of iron in the healthy leaves, without fumagina, smaller than the concentration of calcium, while in the infected leaves the behavior is opposite, the concentration of iron is much larger than the one of calcium. This behavior was observed in all the analyzed species and in natura as in form of tablet. Tables 2 to 5 show the average values and standard deviations for the concentrations obtained from the measurements of three different samples from each leaf type as well as the average values of the detection limits for the samples analyzed.

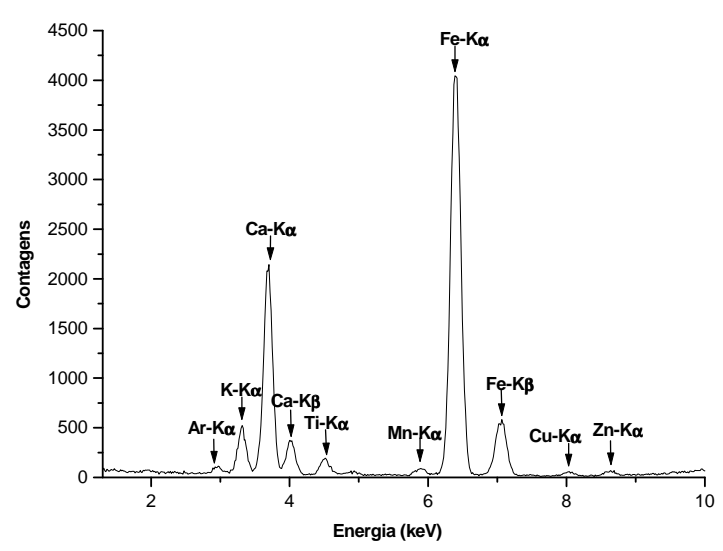

Figure 4 - Typical spectrum of a in natura Bahia orange leave sample with fumagina (time of excitation and detection of $300 \mathrm{~s}$ ) 


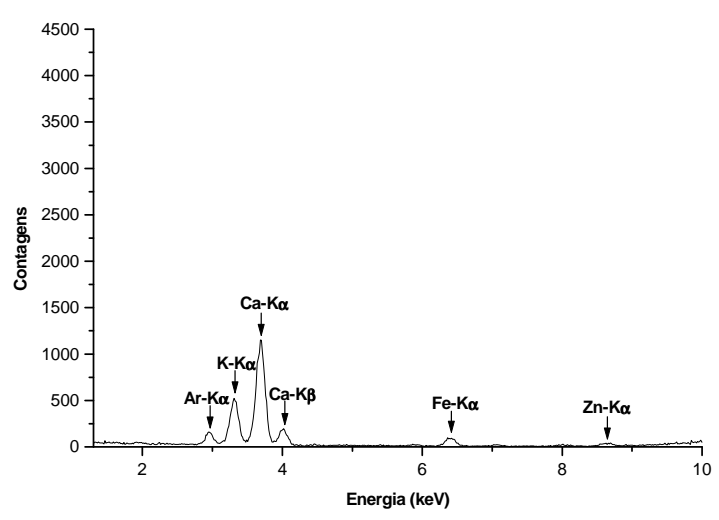

Figure 5 - Typical spectrum of a in natura Bahia orange leave sample without fumagina (time of excitation and detection of $300 \mathrm{~s}$ )

Table 2 - Average concentrations, standard deviations and limits of detection $\left(\mu \mathrm{g} \mathrm{g}^{-1}\right)$ of the elements $\mathrm{Ca}, \mathrm{Ti}, \mathrm{Mn}$, $\mathrm{Fe}, \mathrm{Cu}$ e $\mathrm{Zn}$ determined for Bahia orange leaves samples with and without fumagina. Three different samples for each kind of leaf average results.

\begin{tabular}{ccccccc}
\hline & $\begin{array}{c}\text { Bahia orange } \\
\text { with Fumagina }\end{array}$ & \multicolumn{3}{c}{$\begin{array}{c}\text { Bahia orange } \\
\text { without } \\
\text { Fumagina }\end{array}$} \\
\hline Elements & $\begin{array}{c}\text { Average } \\
\text { Concentration } \\
\left(\mu \mathrm{g} \mathrm{g}^{-1}\right)\end{array}$ & $\begin{array}{c}\text { Standard } \\
\text { Deviation } \\
\left(\mu \mathrm{g} \mathrm{g}^{-1}\right)\end{array}$ & $\begin{array}{c}\text { Limit of } \\
\text { detection } \\
\left(\mu \mathrm{g} \mathrm{g}^{-1}\right)\end{array}$ & $\begin{array}{c}\text { Average } \\
\text { Concentration } \\
\left(\mu \mathrm{g} \mathrm{g}^{-1}\right)\end{array}$ & $\begin{array}{c}\text { Standard } \\
\text { Deviation } \\
\left(\mu \mathrm{g} \mathrm{g}^{-1}\right)\end{array}$ & $\begin{array}{c}\text { Limit of } \\
\text { detection } \\
\left(\mu \mathrm{g} \mathrm{g}^{-1}\right)\end{array}$ \\
$\mathrm{Ca}$ & 94788 & 36273 & 681 & 48862 & 2818 & 1019 \\
$\mathrm{Ti}$ & 111 & 38 & 50 & $<78$ & 3 & 78 \\
$\mathrm{Mn}$ & 32 & 14 & 8.7 & 30 & 3 & 13 \\
$\mathrm{Fe}$ & 704 & 250 & 5.7 & 132 & & 8.6 \\
$\mathrm{Cu}$ & 5.8 & 1.9 & 3.1 & $<4.7$ & 0.6 & 4.7 \\
$\mathrm{Zn}$ & 9.8 & 2.7 & 2.8 & 6.4 & 3.3 \\
\hline
\end{tabular}

Table 3 - Average concentrations, standard deviations and limits of detection $\left(\mu \mathrm{g} \mathrm{g}^{-1}\right)$ of the elements $\mathrm{Ca}, \mathrm{Ti}, \mathrm{Mn}$, $\mathrm{Fe}, \mathrm{Cu}$ e $\mathrm{Zn}$ determined for Valência orange leaves samples with and without fumagina. Three different samples for each kind of leaf average results.

\begin{tabular}{|c|c|c|c|c|c|c|}
\hline & $\begin{array}{l}\text { Valência } \\
\text { orange } \\
\text { with } \\
\text { fumagina }\end{array}$ & & & $\begin{array}{c}\text { Valência orange } \\
\text { without } \\
\text { fumagina }\end{array}$ & & \\
\hline Elements & $\begin{array}{c}\text { Average } \\
\text { Concentration } \\
\left(\mu \mathrm{g} \mathrm{g}^{-1}\right)\end{array}$ & $\begin{array}{c}\text { Standard } \\
\text { Deviation } \\
\left(\mu \mathrm{g} \mathrm{g}^{-1}\right)\end{array}$ & $\begin{array}{l}\text { Limit of } \\
\text { detection } \\
\left(\mu \mathrm{g} \mathrm{g}^{-1}\right)\end{array}$ & $\begin{array}{c}\text { Average } \\
\text { Concentration } \\
\left(\mu \mathrm{g} \mathrm{g}^{-1}\right)\end{array}$ & $\begin{array}{c}\text { Standard } \\
\text { Deviation } \\
\left(\mu \mathrm{g} \mathrm{g}^{-1}\right)\end{array}$ & $\begin{array}{l}\text { Limit of } \\
\text { detection } \\
\left(\mu \mathrm{g} \mathrm{g}^{-1}\right)\end{array}$ \\
\hline $\mathrm{Ca}$ & 125573 & 4295 & 1158 & 103796 & 6632 & 1132 \\
\hline $\mathrm{Ti}$ & $<86$ & & 86 & $<84$ & & 84 \\
\hline $\mathrm{Mn}$ & 70 & 1 & 15 & 59 & 2 & 14 \\
\hline $\mathrm{Fe}$ & 422 & 4 & 9.6 & 170 & 11 & 9.4 \\
\hline $\mathrm{Cu}$ & 133 & 2 & 5.3 & 33 & 2 & 5.2 \\
\hline $\mathrm{Zn}$ & 21.2 & 0.5 & 4.8 & 13.3 & 0.5 & 4.7 \\
\hline
\end{tabular}


Table 4 - Average concentrations, standard deviations and limits of detection $\left(\mu \mathrm{g} \mathrm{g}^{-1}\right)$ of the elements $\mathrm{Ca}, \mathrm{Ti}, \mathrm{Mn}$, $\mathrm{Fe}, \mathrm{Cu}$ e $\mathrm{Zn}$ determined for native orange leaves samples with and without fumagina. Three different samples for each kind of leaf average results.

\begin{tabular}{|c|c|c|c|c|c|c|}
\hline & $\begin{array}{c}\text { Native orange } \\
\text { with } \\
\text { fumagina } \\
\end{array}$ & & & $\begin{array}{c}\text { Native orange } \\
\text { without } \\
\text { fumagina } \\
\end{array}$ & & \\
\hline Elements & $\begin{array}{c}\text { Average } \\
\text { Concentration } \\
\left(\mu \mathrm{g} \mathrm{g}^{-1}\right)\end{array}$ & $\begin{array}{c}\text { Standard } \\
\text { Deviation } \\
\left(\mu \mathrm{g} \mathrm{g}^{-1}\right)\end{array}$ & $\begin{array}{l}\text { Limit of } \\
\text { detection } \\
\left(\mu g^{-1}\right)\end{array}$ & $\begin{array}{c}\text { Average } \\
\text { Concentration } \\
\left(\mu \mathrm{g} \mathrm{g}^{-1}\right)\end{array}$ & $\begin{array}{c}\text { Standard } \\
\text { Deviation } \\
\left(\mu \mathrm{g} \mathrm{g}^{-1}\right)\end{array}$ & $\begin{array}{l}\text { Limit of } \\
\text { detection } \\
\left(\mu \mathrm{g} \mathrm{g}^{-1}\right)\end{array}$ \\
\hline $\mathrm{Ca}$ & 108628 & 17860 & 1087 & 83368 & 1614 & 698 \\
\hline $\mathrm{Ti}$ & 86 & 32 & 81 & 62 & 7 & 51 \\
\hline Mn & $<14$ & & 14 & $<8.7$ & & 8.7 \\
\hline $\mathrm{Fe}$ & 374 & 46 & 9.2 & 192 & 3 & 5.6 \\
\hline $\mathrm{Cu}$ & $<5.0$ & & 5.0 & $<3.1$ & & 3.1 \\
\hline $\mathrm{Zn}$ & 7.3 & 0.7 & 4.6 & 4.7 & 0.3 & 2.8 \\
\hline
\end{tabular}

Table 5 - Average concentrations, standard deviations and limits of detection $\left(\mu \mathrm{g} \mathrm{g}^{-1}\right)$ of the elements Ca, Ti, Mn, $\mathrm{Fe}, \mathrm{Cu}$ e $\mathrm{Zn}$ determined for Tahiti lemon leaves samples with and without fumagina. Three different samples for each kind of leaf average results.

\begin{tabular}{|c|c|c|c|c|c|c|}
\hline & $\begin{array}{c}\text { Tahiti lemon } \\
\text { with Fumagina }\end{array}$ & & & $\begin{array}{c}\text { Tahiti lemon } \\
\text { without } \\
\text { Fumagina }\end{array}$ & & \\
\hline Elements & $\begin{array}{c}\text { Average } \\
\text { Concentration } \\
\left(\mu \mathrm{g} \mathrm{g}^{-1}\right)\end{array}$ & $\begin{array}{c}\text { Standard } \\
\text { Deviation } \\
\left(\mu \mathrm{g} \mathrm{g}^{-1}\right)\end{array}$ & $\begin{array}{l}\text { Limit of } \\
\text { detection } \\
\left(\mu \mathrm{g} \mathrm{g}^{-1}\right)\end{array}$ & $\begin{array}{c}\text { Average } \\
\text { Concentration } \\
\left(\mu \mathrm{g} \mathrm{g}^{-1}\right)\end{array}$ & $\begin{array}{c}\text { Standard } \\
\text { Deviation } \\
\left(\mu \mathrm{g} \mathrm{g}^{-1}\right)\end{array}$ & $\begin{array}{l}\text { Limit of } \\
\text { detection } \\
\left(\mu \mathrm{g} \mathrm{g}^{-1}\right)\end{array}$ \\
\hline $\mathrm{Ca}$ & 91313 & 5164 & 852 & 30967 & 1714 & 703 \\
\hline $\mathrm{Ti}$ & $<64$ & & 64 & $<54$ & & 54 \\
\hline Mn & 15 & 1 & 11 & $<9.2$ & & 9.2 \\
\hline $\mathrm{Fe}$ & 363 & 23 & 7.0 & 44 & 1 & 6.0 \\
\hline $\mathrm{Cu}$ & $<3.9$ & & 3.9 & $<3.3$ & & 3.3 \\
\hline $\mathrm{Zn}$ & 6.9 & 0.2 & 3.5 & 5.9 & 0.5 & 3.0 \\
\hline
\end{tabular}

Tables 2, 3, 4, and 5, showed that for all the species of analyzed leaves samples (Bahia orange, Valência orange, Native orange and Tahiti lemon), there was an increase in the concentrations of $\mathrm{Ti}$, $\mathrm{Mn}, \mathrm{Cu}$ and $\mathrm{Zn}$ in the infected samples with fumagina in relation to the healthy ones, without fumagina. In the infected sample with fumagina high increase was observed in the concentration of $\mathrm{Fe}$ in relation to the one without fumagina. It was also observed that these concentrations were much larger than the limit of detection. For $\mathrm{K}$ and $\mathrm{Ca}$ the technique was not viable for the quantitative determination, presenting limitations for the elements with atomic number smaller than 25 . There were no reports on the quantitative or qualitative values of concentration variation of elements in infected plants with fumagina.
However, in a work with leaves of olive tree from Mediterranean area, Aragão et al.,(2001), observed through the EDXRF technique, observed a metabolic disorder of $\mathrm{Fe}$ and $\mathrm{Ca}$. Analyzing the spectra of healthy olive tree leaves and comparing them with the ones infected by fumagina, they observed that in the healthy leaves, the concentration of $\mathrm{Fe}$ was smaller than $\mathrm{Ca}$ and in the infected leaves with fumagina it was opposite with a quite high amount of $\mathrm{Fe}$ in relation to $\mathrm{Ca}$. The concentration of $\mathrm{Fe}$ measured in the infected leaves of olive trees with fumagina was $80 \mathrm{ppm}$, quite inferior to the observed values in the infected leaves studied in this work. Ivanova, et al.(1999), using the EDXRF technique with radionuclide sources, analyzed the species of healthy plants Pleurozium schreber, Taraxacum officinale, Picea 
abies and Populus nigra "Italica". Table 6 shows $\mathrm{Ca}, \mathrm{Mn}, \mathrm{Fe}, \mathrm{Cu}$ and $\mathrm{Zn}$. the results of the concentrations obtained for $\mathrm{K}$,

Table 6 - Concentrations $\left(\mu \mathrm{g} \cdot \mathrm{g}^{-1}\right)$ measured by Ivanova, et al. in healthy plants leaves

\begin{tabular}{lcccccc}
\hline Plants & K & Ca & Mn & Fe & Cu & Zn \\
\hline Taraxacum officinale & 32200 & 11400 & 24 & & & \\
Populus nigra“Italica" & 2000 & 10000 & 44 & 100 & 0.7 & 31 \\
Pleurozium schreber & - & - & 110 & 153 & 4.1 & 7 \\
Picea abies & 3234 & 3991 & 7 & 16 & 1.5 & 21 \\
\hline
\end{tabular}

Guohui and Shouzhong (1995), using X-ray fluorescence spectrometry, measured 25 elements in the dry powdered plant materials. The results of the concentrations obtained for $\mathrm{K}, \mathrm{Ca}, \mathrm{Ti}, \mathrm{Mn}, \mathrm{Fe}$, $\mathrm{Cu}$ and $\mathrm{Zn}$ can be observed in Table 7 .

Table 7 - Results of elements concentrations $\left(\mu \mathrm{g} \cdot \mathrm{g}^{-1}\right)$ measured by Guohui and Shouzhong in plant samples.

\begin{tabular}{lccccccc}
\hline Plants & K & Ca & Ti & Mn & Fe & Cu & Zn \\
\hline Orchard leaves (USA) & 15200 & 19564 & 28.1 & 94 & 298 & 12.4 & 24.6 \\
Pepper leaves (Japan) & 15815 & 14828 & 7.3 & 2050 & 212 & 342.5 & 342.5 \\
Citrus leaves (USA) & 17132 & 30460 & - & 22.3 & 78 & 25.2 & 25.2 \\
\hline
\end{tabular}

Ajasa et al. (2004), using atomic absorption spectrophotometry measured a total of 10 elements in the powdered medicinal plant samples. The analyzed plant samples were Anacardium occidentale, Azadirachta indica, Butyrospermum paradoxum, Mangifera indica, Morinda lucida, Ocimum canum, Solanum erianthum, Solanum torvum, Zingiber officinale and Hyptis suaveolens. The results of the concentration obtained for elements $\mathrm{K}, \mathrm{Ca}, \mathrm{Mn}, \mathrm{Fe}, \mathrm{Cu}$ and $\mathrm{Zn}$ can be observed in Table 8.
Ajasa et al. (2004), using atomic absorption spectrophotometry measured a total of 10 elements in the powdered medicinal plant samples. The analyzed plant samples were Anacardium occidentale, Azadirachta indica, Butyrospermum paradoxum, Mangifera indica, Morinda lucida, Ocimum canum, Solanum erianthum, Solanum torvum, Zingiber officinale and Hyptis suaveolens. The results of the concentration obtained for elements $\mathrm{K}, \mathrm{Ca}, \mathrm{Mn}, \mathrm{Fe}, \mathrm{Cu}$ and $\mathrm{Zn}$ can be observed in Table 8.

Table 8 - Results of elements concentrations in plant samples (ppm) measured by Ajasa et al.

\begin{tabular}{lcccccc}
\hline Plants & $\mathbf{K}$ & $\mathbf{C a}$ & $\mathbf{M n}$ & $\mathbf{F e}$ & $\mathbf{C u}$ & $\mathbf{Z n}$ \\
\hline A.occidentale & $6380 \pm 25$ & $6103 \pm 15$ & $89.9 \pm 0.03$ & $35.6 \pm 0.02$ & $2.96 \pm 0.01$ & $3.31 \pm 0.02$ \\
A.indica & $19220 \pm 55$ & $3543 \pm 15$ & $46.5 \pm 0.04$ & $188 \pm 0.10$ & $1.12 \pm 0.01$ & $15.7 \pm 0.01$ \\
B.paradoxum & $8170 \pm 16$ & $21850 \pm 40$ & $31.7 \pm 0.06$ & $96.1 \pm 0.05$ & $10.3 \pm 0.01$ & $8.87 \pm 0.01$ \\
M.indica & $7470 \pm 15$ & $18810 \pm 11$ & $133 \pm 0.06$ & $46.6 \pm 0.01$ & $3.07 \pm 0.01$ & $3.24 \pm 0.01$ \\
M.lucida & $13100 \pm 101$ & $51340 \pm 21$ & $685 \pm 0.02$ & $122 \pm 0.02$ & $16.5 \pm 0.01$ & $33.6 \pm 0.01$ \\
O.canum & $36600 \pm 350$ & $32420 \pm 52$ & $51.3 \pm 0.04$ & $241 \pm 0.05$ & $15.1 \pm 0.01$ & $30.8 \pm 0.01$ \\
S.erianthum & $28750 \pm 51$ & $7280 \pm 30$ & $34.1 \pm 0.02$ & $178 \pm 0.05$ & $21.7 \pm 0.01$ & $24.2 \pm 0.01$ \\
S.torvum & $31550 \pm 102$ & $11390 \pm 20$ & $48.7 \pm 0.06$ & $208 \pm 0.03$ & $13.9 \pm 0.02$ & $23.4 \pm 0.01$ \\
Z.officinales & $25280 \pm 113$ & $2610 \pm 10$ & $413 \pm 0.70$ & $144 \pm 0.05$ & $14.4 \pm 0.01$ & $33.3 \pm 0.01$ \\
H.suaveolens & $18260 \pm 233$ & $19780 \pm 8$ & $39.4 \pm .0 .30$ & $142 \pm 0.10$ & $24.4 \pm 0.01$ & $35.1 \pm 0.01$ \\
\hline
\end{tabular}

Comparing the results of Table 6 with those of this work for healthy leaves (Tables 2 to 5), it could be observed that the range of concentration of Fe in both works had the same order of magnitude. Ivanova et al. (1999), didn't present any results for Ti. The values obtained for the range of concentration of $\mathrm{Mn}$ were equivalent in both the works. For $\mathrm{Zn}$, the range of concentration measured by Ivanova et al. (1999), was a little higher than that measured in 
this work, while for $\mathrm{Cu}$, the range obtained in the present work was quite superior to that measured in the plants analyzed by Ivanova et.al. (1999). Comparing the results of Table 7 for the Citrus leaves samples with those of this work for healthy leaves (Tables 2 to 5), it could be observed that the range of $\mathrm{Fe}, \mathrm{Mn}$ and $\mathrm{Cu}$ concentrations in both the works had the same order of magnitude. Guohui and Shouzhong (1995), didn't present any results for Ti. For Zn, the range of concentration measured by Guohui and Shouzhong (1995), was a little higher than that measured in this work. Comparing the results of Table 8 with those of this work for the healthy leaves (Tables 2 to 5), it could be observed that the concentrations of $\mathrm{Fe}$ and $\mathrm{Zn}$ were a little higher than those measured in this work. Ajasa et al. (2004), didn't present any results for $\mathrm{Ti}$. The values obtained for the concentration of $\mathrm{Mn}$ were higher than that measured in this work. For $\mathrm{Cu}$ the range of concentration measured by Ajasa et al. (2004), was a little smaller than that measured in this work.

\section{CONCLUSIONS}

The obtained results employing the three different samples preparation methods resulted in similar conclusions for the various elements behavior comparing healthy and infected leaves. In healthy leaves samples, without fumagina, the obtained concentrations for the analyzed elements varied from 44 to $192 \mu \mathrm{g} \cdot \mathrm{g}^{-1}$ for $\mathrm{Fe}, 54$ to $84 \mu \mathrm{g} . \mathrm{g}^{-1}$ for Ti, 8.7 to $59 \mu \mathrm{g} . \mathrm{g}^{-1}$ for $\mathrm{Mn}, 4.7$ to $13.3 \mu \mathrm{g} . \mathrm{g}^{-1}$ to $\mathrm{Zn}$ e 3.1 to $33 \mu \mathrm{g} \cdot \mathrm{g}^{-1}$ to $\mathrm{Cu}$. The obtained concentrations in samples of infected leaves with fumagina varied from 363 to 704 $\mu \mathrm{g} . \mathrm{g}^{-1}$ for the element $\mathrm{Fe}, 64$ to $111 \mu \mathrm{g} \cdot \mathrm{g}^{-1}$ for Ti, 14 to $70 \mu \mathrm{g} . \mathrm{g}^{-1}$ for $\mathrm{Mn}, 6.9$ to $21.2 \mu \mathrm{g} \cdot \mathrm{g}^{-1}$ for $\mathrm{Zn}$ and from 3.9 to $133 \mu \mathrm{g} . \mathrm{g}^{-1}$ for $\mathrm{Cu}$. The concentration of $\mathrm{Fe}$ in the leaves infected by fumagina, in relation to the healthy ones increased by a factor 5.3, 2.5, 1.9 and 8.2, respectively for the leaves of Bahia, Valência and native oranges, and Tahiti lemon. Comparing the citric species among themselves, it can be observed that the Tahiti lemon leaves were more affected by fumagina than the three orange species leaves. In the EDXRF qualitative determination of $\mathrm{K}, \mathrm{Ca}, \mathrm{Ti}, \mathrm{Mn}, \mathrm{Fe}, \mathrm{Cu}$ and $\mathrm{Zn}$ in samples of citric plants leaves analyzed in natura and in the form of tablet of the pure material of leaves powder, it was possible to observe clearly the effects of fumagina in the several analyzed species, whose behavior was identical to the measured in the quantitative analyses.

\section{ACKNOWLEDGEMENTS}

The authors would like to thank CAPES, Brazil, for the financial support for this work.

\section{RESUMO}

Foi empregada a técnica de fluorescência de raios X por dispersão de energia (EDXRF), para estudar os efeitos da doença fumagina na composição química elementar de folhas. $\mathrm{O}$ arranjo experimental consistiu de um tubo de raios $\mathrm{X}$ com anodo de $\mathrm{Mo}\left(\mathrm{K}_{\propto}=17.44 \mathrm{keV}\right) \mathrm{com}$ filtro de $\mathrm{Zr}$ e um detector de $\mathrm{Si}(\mathrm{Li})$. As medidas foram realizadas com folhas de plantas cítricas infectadas e sadias. Foram quantificados os elementos Ti, $\mathrm{Mn}, \mathrm{Fe}, \mathrm{Cu}$ e $\mathrm{Zn}$, com um limite de detecção médio de $69,12,8,4$ e $4 \mu \mathrm{g} \cdot \mathrm{g}^{-1}$ respectivamente. As concentrações obtidas para o Fe variaram de 44 a $192 \mu \mathrm{g} . \mathrm{g}^{-1} \mathrm{em}$ amostras de folhas sadias e de 363 a $704 \mu \mathrm{g} \mathrm{g}^{-1}$ para as folhas infectadas com fumagina.

\section{REFERENCES}

Ajasa.A. M. O, M. Bello.O, Ibrahim.A. O, Ogunwande I. A, Olawore.N. O (2004) Heavy trace metals and macronutrients status in herbal plants of Nigeria. Food Chemistry 85, p.67-71.

Almeida, F. A., Araujo, E., Goncalves J., Hermes et al. (2003) Diagnóstico e quantificação de doenças fúngicas da acerola no Estado da Paraíba. Fitopatol. bras., mar./abr. vol.28, no.2, p.176-179. ISSN 0100-4158.

Aragão.P.H.A, Cesareo. R., Fernandes E.A, Balogun.F, Prota. U, Fiori. M(2001) - Iron in olive tree leaves in the Mediterranean area. Journal of Radioanalytical and Nuclear Chemistry, v.249, p.509-512.

Bertin.E. P (1975)- Principles and pratice of X-ray spectrometric analysis. London: Plenum Press, $1079 p$. 
Espen P. V, Nullens.H, Adams F (1977). A computer analysis of X-ray fluorescence

spectra. Nuclear Instruments and Methods, v. 142, p. 243-250.

Fanta. N., Quaas. A, Zulueta.P, Perez L. M(1992)Release of reducing sugars from citrus seedlings, leaves and fruits. Effect of treatment with pectinase and cellulase from alternaria and trichoderma. Phytochemistry, v.31, p.3359-3364.

Giauque.R. D. Goulding.F.S, Jaklevic.J.M, Pehl.R.H (1973). Trace element determination with semicondutor detector X-ray spectrometers. Analitical Chemistry, Washington, v.45, n.4, p.671-681.

Guohui. L, Shouzhong. F(1995) - Direct determination of 25 elements in dry powdered plant materials by X-ray fluorescence spectrometry. Journal of Geochemical Exploration 55, p.75-80.

Ivanova. Ju, Djingova.R, Kuleff.I(1999) Possibilities of ED-XRF with radionuclide sources for analysis of plants. Radioanalytical and Nuclear Chemistry, v.242, p.569-575.

Lachance G.R, Claisse. F (1994) - Quantitative XRay Fluorescence Analysis Theory and Aplication, John Wiley and Sons 400p.

Nascimento Filho, V. F. (1993). Técnicas analíticas nucleares na pesquisa agropecuária: Fluorescência de raios $X$ e Ativação neutrônica. Centro de Energia Nuclear na Agricultura/CENAESALQ/USP, Piracicaba p.1-24.

Received: July 07, 2005; Revised: January 22, 2006; Accepted: April 30, 2007. 